\title{
Carrosséis urbanos: da racionalidade moderna ao pluralismo temático (ou territorialidades contemporâneas)
}

\author{
Maria Bernardete Ramos Flores \\ UFSC \\ Emerson César de Campos \\ UDESC
}

\section{RESUMO}

A cidade é uma instância significativa na "desordem" do mundo contemporâneo. É nela que, por assim dizer, a vida acontece. Para aqueles que têm nela seu foco de estudo, se torna um desafio diário a compreensão desta pulsante existência. Partindo de dois exemplos empíricos, Blumenau e Criciúma, duas cidades de Santa Catarina, o artigo aborda questões da cidade contemporânea. Se não se podem descrever as cidades, que já não se pautam pelo modelo moderno, racional, integrada em suas conexões totalizantes, não significa que não se possa abordá-las como lugares praticados, em seus territórios e fluxos capazes de articular, de misturar, elementos díspares, antagônicos, inusitados. Seguindo esta perspectiva buscamos, na medida do possível, detalhar a constituição de espaços e tempos na cidade onde a polifonia demarca territórios, promove inclusões e exclusões sociais, inventa linguagens e símbolos, arranja identificações, cria novos sujeitos, afeta desejos, inova mercado e mercadorias.

Palavras chaves: Cidade contemporânea; imagem; polifonia.

\section{ABSTRACT}

The city is a significant instance in the "disorder" of the contemporary world. It is in it that life happens. It is a daily challenge to understand its existence. Starting from two empiric cases, Blumenau and Criciúma, two cities of Santa Catarina, the article approaches subjects about the contemporary city. Nowadays, if we cannot describe the cities, that no longer are ruled by the modern and rational model, integrated in their totalized connections, it doesn't mean that we cannot approach them as practiced places, in their territories and flows, capable to articulate or mix, unequal, antagonistic and unusual elements. Following this perspective we try to detail the constitution of spaces and times in the city, where the polyphony demarcates territories, promotes inclusions and social exclusions, invents languages and symbols, provides identifications, creates new subjects, affects desires, innovates the market and goods.

Keywords: Contemporary city; image; and polyphony. 
Você mora em uma cidade, você gosta e não gosta dela, você imagina às vezes outras soluções que não as que têm sido adotadas, e está assistindo agora, em uma sala pública, à apresentação de 'sua' cidade realizada por profissionais da imagem que nunca confessarão que detestam a sua cidade. Mas pode-se verdadeiramente detestar uma cidade? E quais seriam as razões? Sua ausência de centro? Seu aspecto desordenado? A feiúra de suas construções? Sua violência cotidiana? Todas as razões para detestá-la terminam por lhe conferir um atrativo. Assim é a natureza humana, que se deixa estranhamente atrair pelo que crê abominar. ${ }^{1}$

\section{OlHANDO A CIDADE OUTRA VEZ...}

Encontrar uma via nova para falar de algo tão antigo como as cidades. Assim no plural, então, o desafio é muito maior. Buscamos um encontro com narrativas que possam simultaneamente falar de muitas cidades, mantendo nelas suas singularidades. Heloísa Buarque de Hollanda já colocou, à guisa de introdução na revista do Patrimônio Histórico e Artístico Nacional, ${ }^{2}$ a incerteza na opção: cidades ou cidade. Naquela oportunidade, a ensaísta, refletindo a partir das implicações do patrimônio cultural, acabou optando pelo termo no singular. Nossa escrita é complementar e, para além de mero formalismo semântico, gostaríamos de marcar que pensamos na cidade enquanto tema, mas também como a costura de espaços, enquanto lugares praticados, das inscrições dos corpos, da reverberação das falas, dos (des)encontros; as cidades dentro da cidade, neste presente que, na falta de nominação, chamamos contemporâneo. Assim, lembrando Sandra Jatahy Pesavento, "um fim e um começo, mas sempre a cidade". ${ }^{3}$

Os escritos sobre as cidades no Brasil se construíram, ou ainda em alguma medida se constroem, sob uma tradição. As cidades, como grande obra do século XIX, sintetizadas na sensibilidade burguesa diante do espetáculo da multidão nas ruas, na sua inquietação com a concentração humana num mesmo espaço, na organização da vida urbana presa às fábricas e no movimento alucinante das pessoas e mercadorias, tinham um caráter próprio de observação, análise e intervenção. A formação da multidão, a organização espacial e temporal do trabalho fabril, o trabalho industrial, o desemprego industrial, a falta de moradias, a criação do tempo artificial marcado pelo relógio mecânico, a criminalidade, desembocaram numa obra urbana, fruto dos planejamentos urbanos e políticas públicas, tais como saneamento, abertura de gran- 
des avenidas, demolição dos cortiços, arquitetura funcionalista. O projeto urbano tinha como objetivo controlar as doenças epidêmicas, a ameaça das classes perigosas, a rejeição ao trabalho disciplinar, criar novos padrões de moral e comportamento, dar visibilidade e mobilidade ao espaço urbano.

Diante da complexidade desse urbanismo moderno, os instrumentos e códigos de identificação e deciframento das cidades medievais ou coloniais tornaram-se inúteis. Como enquadrar o conjunto de estranhos que chegavam dos campos feudais, no caso da Europa, ou das lavouras cafeeiras ou canaviais brasileiros, com seus hábitos, maneiras de vestir, comportamentos e culturas tradicionais, avessos ao trabalho fabril e à economia liberal de mercado? Como identificar, classificar, conhecer, representar, intervir, dominar, no meio urbano, a ameaça de revolta, o perigo da peste, o indício da doença, o prenúncio da desordem? Sobre essa nova realidade social, econômica e cultural é construído um modelo de poder e dominação da cidade. Uma maneira própria de conhecer, abordar, olhar, dominar e construir a cidade, que é invenção do século XIX, representada pela modernização de Paris, com as obras de Haussmann. Modelo, este, que se tornou o paradigma da cidade moderna e que se espalhou pelos quatro cantos do mundo. A cidade passou a ser pensada e construída como um sistema racional, possível de ser pensada como um objeto passível de planificação, apreendido em sua totalidade. Higienistas, médicos e engenheiros são os sujeitos dessa construção. Treinam o olhar, esquadrinham a cidade e visibilizam os corpos dos cidadãos para ter sobre eles o controle sobre sua saúde, sua moradia, seus passos pela cidade, seu trabalho, seu lazer e sua sociabilidade, suas organizações sociais e políticas, seu consumo. Assim, a cidade racionalizada, disciplinada, é ela própria pensada como uma cidade-corpo, objeto de detalhadíssimo olhar do médico e do engenheiro, objetivando construir uma cidade estetizada (pela arquitetura), ou uma cidade reformada (pelas obras de engenharia e topografia), ou uma cidade saneada (pela intervenção do médico). Esse conjunto de equipamentos e intervenções sobre a cidade constituiu um modelo de cidade - a cidade moderna - pautada pela racionalidade técnica e científica dos planejamentos urbanos. ${ }^{4}$

Hoje esse modelo está em crise. Fala-se em cidade imagem, cidade turística, cidade-cultura, cidade evento, cidade-ecológica, cidade da moda, para as quais os paradigmas interpretativos da cidade moderna já não são mais eficientes. Ao capital financeiro e industrial costuma-se adicionar o 'capital cultural'. A competição internacional produziu uma mutação das tradicionais cidades industriais em cidades de arte ou de cultura. Na Itália, por exemplo, 
Florença e Veneza são atualmente cidades de arte; Milão se transformou de cidade industrial em cidade da moda, do design, da publicidade, das TVs particulares; Roma é em parte cidade-arte e em parte cidade-cultura. De outra feita, a esquizofrenia das grandes metrópoles esbarra em qualquer tentativa de definição de identidade, com suas áreas marginais sem territorialidade física esboçada, com suas múltiplas redes de sociabilidades. É “a imagem de uma cidade dividida em áreas estanques com conteúdos próprios”, que rompe com os conceitos urbanos do século XIX, "na medida em que rompe com a noção de identidade, de objetividade, de subjetividade racionalmente constituída, e outros mitos vitorianos". ${ }^{5}$

Enquanto isso, nas cidades, lugares praticados, territórios e fluxos contemporâneos

Há muito ainda a pensar sobre esse objeto de cultura. Se não se podem descrever as cidades, que já não se pautam pelo modelo moderno, racional, integradas em suas conexões totalizantes, não significa que não se possa abordá-las em seus territórios e fluxos, como lugares praticados. Alguns trabalhos mais recentes apresentam possibilidades distintas do chamado 'modelo moderno'. Parece ser esse o caso do estudo coordenado por Catherine BidouZachariasen, sob título: De volta à cidade: dos processos de gentrificação às políticas de 'revitalização' dos centros urbanos. ${ }^{6}$ Mas, ainda assim, nele se discute mais urbanismo, menos urbanidade, mais espacialização e menos lugares praticados.

Transitar pela cidade. Esta é a atividade mais próxima do momento, mais distante das estabilidades, menos morta da vida citadina, mais íntima das superfícies. Não mais falamos da flânerie - ao menos não como uma referência central - porque a idéia de centro e mesmo de preeminência, já não é mais possível ser posta de modo tão puro, tão solidamente moderno. O flâneur foi dessacralizado de sua aura moderna. A urbanidade contemporânea dá conta de produzir uma série de outras possibilidades: rappers, catadores de recicláveis, yuppies, mendigos, que vivem ou sobrevivem em meio a galerias, vitrinas, ruínas da modernidade, shopping centers, enfim, 'nossa barulheira' contemporânea, que nos separa da flânerie moderna, tão vivamente discutida por Walter Benjamin. Em Paisagens imaginárias, Beatriz Sarlo, discorrendo sobre a 'moda Benjamin' que se impõe na década de 1980, tendo em foco a cidade, mostra como é frágil a simples transposição de uma concepção do início do século XX para a entrada do século XXI. Diz Sarlo: 
O simples passeante verpertino de uma praça interiorana ou de um calçadão que não tem mais do que duas quadras tornou-se personagem de um romance filosófico urbano, esboçado conforme a teoria benjaminiana sobre a modernidade no século XIX ou sobre as ruínas do capitalismo na vitrina de suas mercadorias. ${ }^{7}$

Acrescenta-se ao que é exposto por Sarlo a ressalva de que no contemporâneo, mesmo em cidades onde na maior parte das vezes o calçadão não ultrapassa duas quadras, o 'passeante vespertino' que caminha sobre as ruínas da modernidade não é mais 'simples'. Vivemos o tempo 'ex-cêntrico'. Mais que um plural, coloquemos diferenças nisto: 'ex-cêntricos'. Para a leitura das cidades no contemporâneo, isto é decisivo. Antes, referências para se pensar metrópoles; hoje, ante as ruínas da modernidade, as cidades comunicam coisas. Amplia-se a demanda por novas referências. Não existe isomorfismo entre espaço, lugar e cultura, como indicam Akil Gupta e James Ferguson. Estes antropólogos mostram como as manifestações culturais perderam suas amarras a lugares definidos, ressaltando a importância da diferença cultural. A identificação de um lugar é produzida na "interseção entre seu movimento específico em um sistema de espaços hierarquicamente organizados e sua construção cultural como comunidade ou localidade". Há uma relação tensa entre lugar e identidade que precisa ser pensada, em vez de negada ou ignorada. ${ }^{9}$

O alvo hoje não é a questão do autêntico ou do genuíno, mas a performatividade. A produção de imagens identificadoras. O capitalismo globalizante trouxe em sua esteira, e busca, em sua maior parte, uma invocação por uma identidade regional ou local, como forma de fugir das grandes homogeneidades e manter o caráter de singularidade no grande mercado mundial, para que possa aparecer como mais 'um' concorrente. Assim, as construções ditas locais não se exibem como simples manifestações de uma expressão cultural contrária às tendências entendidas como cosmopolitas, tampouco se colocam de modo tranqüilo numa espécie de volta a uma 'época de ouro' em que uma tradição daria conta de proteger (e fortalecer). Em suas construções contemporâneas o localismo incorpora (mesmo dentro da tradição) elementos e ferramentas cotidianas como a televisão, os alimentos industrializados, o computador, o celular e outros tantos. As cidades contemporâneas avolumam territórios onde isso é comunicado diariamente. Assim, identidade não é o resultado fechado de heranças culturais, mas a produção contínua e dolorida de criações diárias, inseridas no jogo social. Por isso, parte significativa dos trabalhos sobre fluxos contemporâneos tem considerado, de modo mais 
amplo, as identificações. Isso é uma possibilidade de pensar elementos que tentam estabelecer regras e lugares próprios a grupos ou sujeitos fora de uma dimensão unívoca ou de uma identidade hermética. Disso resulta entre outros pontos o chamado 'hiperespaço', termo criado para delinear o lugar do excesso do qual o contemporâneo é constituído, ${ }^{10}$ colocando em suspeição a convicção de que culturas possam ser mapeadas sobre lugares e povos, menos ainda onde estes se materializam, ou seja, nas cidades.

Michel de Certeau nos mostra que os espaços (social, político, físico) são sempre lugares praticados, configurações instantâneas de posições. ${ }^{11}$ Entre as duas determinações - espaço e lugar —, as pessoas transitam, exigem passagens. Nas cidades contemporâneas, onde os fluxos são intensos, para além de um 'próprio' do lugar, 'o aqui e o lá' ficam embaçados e a idéia fixa de enraizamento é estremecida. Assim se instala a ruptura significativa entre cultura e espaço, ou melhor, entre cultura e lugar. A fixidez que a tradição atribui aos lugares em muito já vazou para outros tantos. Existe a fluidez do contemporâneo. As diferenças não podem ser analisadas tendo-se como referência a distância, quase sempre apresentada em metros, ou quilômetros, reverberada em expressões do tipo: 'a violência não chega aqui', 'isto é coisa da periferia', 'nesta cidade se trabalha', e outras tantas.

Fora do lugar-comum de se enxergar ações polarizadas entre as populações do centro e da periferia, e para além de uma simples integração de ambas possibilidades, as produções culturais da cidade indicam este deslocamento: o lugar intervalar onde, não esquecendo as diferenças, inscritas sejam elas na expressão corporal, na vestimenta ou mesmo no alimento ingerido, as negociações se apresentam. Falamos então de uma temporalidade e de uma espacialidade, capazes de articular, de misturar, elementos díspares, antagônicos, inusitados. Seguindo esta perspectiva buscamos, na medida do possível, detalhar a constituição de espaços e tempos na cidade onde a polifonia, por exemplo, demarca territórios, promove inclusão e exclusão sociais, inventa linguagens e símbolos, arranja identificações, cria novos sujeitos, afeta desejos, inova mercado e mercadorias.

\section{A POLIFONIA CITADINA}

A realidade cultural vivida em Criciúma, ${ }^{12}$ ao sul de Santa Catarina, 'tradicionalmente' conhecida como 'capital brasileira do carvão', se constitui em exemplo de uma polifonia citadina contemporânea. Territórios antes interdi- 
tados (ao menos até a década de 1980), agora se exibem e promovem ecos. Desta forma os espaços constituídos em festas e sons (a exemplo da Quermesse ou Festa das Etnias e do Rap) se constituem em elementos significativos dessa cidade catarinense.

Até o início da década de 1990, a cidade mineradora de Criciúma tinha ainda as marcas do carvão, cujo auge da exploração fora entre as décadas de 1940 e 1970. A partir dos anos 80, a decadência, o empobrecimento, a poluição, a incerteza. Hoje, é possível afirmar que após uma série de investimentos de amplos setores, a cidade respira ares menos densos, mais polifônicos. Tradicionalmente pensada como uma cidade pouco cosmopolita e de alguns poucos privilegiados, onde práticas sociais estariam congeladas em seus monumentos, principalmente os destinados aos colonizadores, pode-se dizer que Criciúma apresenta outros sindemos encontrar rodas de capoeira, cuja inscrição no lugar dança e grita a ais no contemporâneo. Caminhando nela, pomudança. Ao som do berimbau, a capoeira desafia a solidez de uma tradição, fazendo a roda em frente ao Colégio São Bento, no chão da Praça do Congresso, lugares que antes foram da elite. O lugar agora está definitivamente impregnado de 'Outros', de um 'Outros' de nós mesmos. Outros que são produzidos fora de uma dimensão dolorosa e ressentida. Como poderia tal prática ser vista e mesmo apoiada pelo poder público, pela Fundação Cultural de Criciúma?

No contemporâneo citadino, os elementos culturais quase sempre estão mais ligados ao momento do que a um lugar perfeitamente delimitado. Há que se revirar os lugares, tal qual a prática posta com humor pelo "Circo do Revirado" em Criciúma. É no cruzamento dessas referências que se pode perceber a força da negociação e a instabilidade dos lugares. Conforme dito, duas décadas atrás, Criciúma era bem menos 'cosmopolita', para usar um termo de fácil compreensão, e bem mais étnica, no sentido da preservação de raízes. Para além da força expressiva da capoeira, vista como prática antiga entre brasileiros, e que justamente por carregar esta 'antiguidade' pode ser entendida ainda de forma tradicional, o contemporâneo criciumense vive outras possibilidades.

O ritmo se coloca. É certo que lugares, mesmo que tenham pretensamente a idéia de estabilidade, não aliviam tensões. Willian Santiago Bernardo, 30 anos, é rapper do Grupo Ato Consciente, de Criciúma. Através do rap cantado pelo grupo se pode ter uma idéia do que é viver numa cidade contemporânea, em seus entre lugares, vincando territórios na cidade.

Lá na zona Sul, irmão, não é diferente, o rap é quente, muita gente tá dizendo idéia forte. No Clube Operária, pode crer, é nossa área, hip-hop não desanda por- 
que tem idéia forte ... Skate, rap, um garrafão de vinho para esses manos, com a mina eles amanhecem em grande estilo, o que é aquilo?, aquele cara está chegando, é o Fernando, olha só que pinta de malandro, é Nike Jordan no pé, na cabeça o boné e tá mascando chiclé ... Na Cesaca é o que rola, os parceiro tão ligado se chover é embaçado, outro dia estava lá no terminal central ... tá chegando o amarelinho quem tá dentro é o povinho... ${ }^{13}$

O rapper fala da cidade de dentro dela. ${ }^{14} \mathrm{~A}$ linguagem e as letras instauram diferenças. O Clube União Operária ${ }^{15}$ é um dos territórios da cidade onde a expressão afro-descendente é vigorosa, se inserindo na polifonia criciumense. $\mathrm{Na}$ Cesaca, antiga fábrica da cidade, posteriormente transformada em pavilhão de eventos há o encontro, e 'rola o som'. O território é assim mesmo, ao ar livre e na rua quase sempre, por isto, se chover fica 'embaçado'. No trânsito vai chegando o amarelinho, o ônibus de linha circular da cidade, que pode levar todos à Zona Sul, onde não é diferente, 'o som rola e o bicho pega'. Esta é a territorialização local, também atravessada por outras referências. $\mathrm{O}$ próprio rap do Ato Consciente é muito resultado disto. As referências iniciais do rap foram forjadas em territórios afro-americano, ainda em fins da década de 1960. O Ato Consciente deixa claro alguns ícones da expressão rapper americana: "É Nike Jordan no pé, na cabeça o boné". Mais que isto, o rap na cidade acaba contribuindo para ampliar a visibilidade e a discussão pública de uma série de tensões vividas não apenas pelos afro-descendentes, mas por boa parte das pessoas que vivem em territórios onde a falta de perspectivas é uma constante. Ao falar de emprego, violência, diversão e outros tantos temas, o Ato Consciente mostra que, como diz uma das suas músicas, "malandragem de verdade é viver”. As apresentações do grupo acontecem em muitos lugares da cidade: boates, bairros da periferia, no calçadão da Praça Nereu Ramos, na "Quermesse: Tradição e Cultura" e, apesar do protesto de alguns, em shopping centers também.

Se nos detivermos nos sons e territórios vividos em Criciúma, nos aparece de forma mais clara a sua dinâmica contemporânea. A Praça Nereu Ramos, território inicial da Quermesse (da qual falaremos mais adiante), está repleta dessas referências. Continua sendo o lugar de protestos, mas também de exibições, feirinhas, músicas, placas, monumentos, shopping e outras tantas possibilidades, que fragilizam a idéia de que exista algo de próprio nos lugares. Mais que um Centro Histórico ela é hoje um grande Parque Temático; sim, pois é de se perguntar: a quem interessaria transformar a cidade, em sua dinâmica atual, num grande museu, ainda que de novidades? ${ }^{16}$ Por certo po- 
demos identificar muitas tentativas de consagrar aos lugares uma estabilidade. Mais que um centro a ditar o urbano e construir territórios, existe hoje a 'ex-centro-cidade', categoria que recentemente reivindicou para si, em campanha publicitária, um distrito de Criciúma: "Rio Maina, aqui é minha cidade".

A campanha, iniciada em novembro de 2003, vem se repetindo a cada final de ano. Comerciantes junto ao CDL local distribuem camisetas, folders e outros brindes pelo distrito, especialmente, é claro, em suas áreas mais carentes. Nestor Garcia Canclini ${ }^{17}$ fala dessa relativa independência que bairros e distritos têm alcançado nas cidades contemporâneas, provocada pelo desenvolvimento mais adequado e próximo do comércio, dos ambulatórios médicos e outros equipamentos urbanos. Também é o que afirma de forma muito semelhante o sociólogo e filósofo francês Henri-Pierre Jeudy: "A oposição entre o centro e a periferia não é mais tão determinante, no momento em que as megalópoles se tornam elas mesmas gigantescos subúrbios". ${ }^{18}$ Isto é particularmente importante para se pensar as relações estabelecidas (e as leituras que realizamos) entre grandes centros e periferias e, internamente, nas cidades, as relações de um dito centro histórico com suas inúmeras constituições territoriais.

Assim, territórios étnicos, comunicacionais e gastronômicos, se cruzam e constroem sentidos. Oralidade e musicalidade fornecem, em grande medida, os tons do contemporâneo em Criciúma. Isto, óbvio, também implica reconhecermos a necessidade de um cuidado maior entre o global e o local, bem como com as diferenciações produzidas nessa articulação. Como mostra Stuart Hall, "a globalização de fato explora a diferenciação local. Desta maneira, ao invés de pensar na substituição do global pelo local, seria mais cuidadoso pensar em uma nova articulação entre global e local". ${ }^{19}$ Criciúma é uma cidade que tem pouco mais de três dezenas de bairros. É vista hoje como ex-capital do carvão, terra das etnias, capital do azulejo, terra da emigração, ${ }^{20}$ ou atributos outros que possam ser aventados, onde os lugares e circunstâncias se constituem em imbricadas manifestações híbridas ${ }^{21}$ que nada têm de serenas e tranqüilas.

\section{Quermesse de Tradição e Cultura: PLURALISMO TEMÁTICO E DIFERENÇAS CULTURAIS}

A cidade de Criciúma, especialmente lá onde uma vez fora o seu 'Centro', teve seu início marcado por cruzamentos de caminhos, ainda no final do sé- 
culo XIX. Entre esses caminhos, os mais reconhecidos na história da cidade são aqueles abertos pelos tropeiros e os abertos pelos imigrantes (especialmente italianos). Nesse 'cruzamento' instaurou-se o Parque das Etnias, ${ }^{22}$ bem junto ao Paço Municipal de Criciúma. Nele, realizou-se a XIII Quermesse de Tradição e Cultura, também chamada de Festa das Etnias, para exibir performances portuguesas, polonesas, alemãs, italianas, africanas, árabes e até indígenas.

A constituição ou organização de uma quermesse parece ser motivada por uma ação solidária em forma festiva. Se empiricamente quase todos nós trazemos uma idéia de quermesse, campear um tino mais elaborado não constitui uma tarefa muito simples. A maior parte dos registros, seja ela oriunda da tradição oral ou da literatura, concebe a quermesse como uma feira paroquial, com folguedos populares, um bazar onde se podem encontrar as mais variadas miudezas. ${ }^{23}$ Uma grande feira, enfim. É possível por um 'agora', num tempo minúsculo de um sorriso, lembrar outras quermesses, aquelas em que apostando algumas parcas economias, se torcia para ganhar "uma garrafa de vinho e uma camisa marrom", prêmios anunciados por um microfone de efeito quase pífio. Contudo, ao calar o sorriso, o som que se ouve é outro bem diferente. O som agora é high-tech, e o que ele produz naqueles que se deixam perder nos seus harmônicos, se encontra distante da monofonia do outro 'agora’. Um locutor sobrepõe outras vozes. Há agora uma polifonia. Imersa nela, a voz sobreposta convida a todos para que visitem o museu Casagrande, "antiga casa de um dos colonizadores da cidade". O convite ainda se estende à "irresistível prova de um pierogi polonês".

Na tenda portuguesa há um fado que se pode ouvir ao fundo. Ele se confunde com o pop Planeta dos Macacos. Bem ornada e alinhada, se dispõe pela tenda uma série de painéis, tentando fixar imagens da presença portuguesa em solo brasileiro ao mostrar como se deu a construção territorial do imponente achamento português desde o século XVI. A comida oferecida, bem cuidada, proporciona um agradável aroma. O cardápio sinaliza: bacalhau, batatas e doce de abóbora com cravo.

À mesma rua, o pierogi pode ser saboreado. Ele se transfigura, se materializa na tenda polonesa. Nesta já não há um fado, mas sim uma música capaz de permitir àqueles que possuem habilidade de ligar sons a lugares, talvez uma viagem a Cracóvia ou Varsóvia. Nessa tenda há uma bandeira polonesa, a informar os desavisados da territorialidade do espaço. Ela se confunde com outra bandeira de um grupo folclórico que tenta 'resgatar' a cultura polonesa.

Nesse passeio, à mesma rua, se encontra uma terceira tenda. A língua é a mesma das outras tendas, se fala nela o português. Mas existe uma série de 
outros sinais que a diferencia das demais. Um senhor colocado à sua entrada comunica a todos a urgência em se saborear a comida, afinal esta "é a única oportunidade no ano em que servimos comida alemã na cidade”. As bandeiras não se repetem, elas são mesmo outras. Agora lembram alguma região ou cidade da Alemanha. A comida já não é o pierogi ou o bacalhau. Come-se marreco recheado e chucrute, e a sobremesa é strudel. Orgulhosamente, a tenda se mostra como a única a apresentar música ao vivo: uma bandinha alemã.

Agora os brasões e bandeiras são outros. Eles anunciam a territorialidade italiana. É outra também a comida: polenta, galinha e massas são os pratos a produzir o aroma da tenda. Alguém anuncia a tarantela como música 'típica italiana', enquanto no palco em frente um grupo folclórico encena a música da paquera siciliana. Nesse momento, as diferenças entre sicilianos e italianos do norte estão circunscritas a um outro lugar, em outras tendas.

A situação, disposta à mesma rua, agora já é outra. Uma senhora à entrada da tenda está muito bem vestida com um manto à tigresa e um turbante à cabeça, anunciando outros lugares, de identificação mais imprecisa, nem por isso menos visível. É a tenda da etnia negra. Carrancas e máscaras ornamentam as paredes. As bandeiras são muitas, e numa profusão de cores tentam dar conta de outros lugares: Guiné-Bissau, Angola e Jamaica. O cardápio consiste em peixe, camarão, saladas e um saboroso doce de leite como sobremesa.

Em outra tenda é hora de receber visitas. Não muito à vontade, preparando um kafta, o governador do estado junto a sua esposa e outras tantas autoridades, está na tenda árabe. Faz dois dias que o mundo assistiu ao desabamento das duas torres do World Trade Center, em Nova York. A configuração aguça a curiosidade e o número de pessoas na tenda é grande. Papiros, cristais, véus, bijuterias egípcias, caixas de madrepérola, gabbehs, lanternas, e num canto da tenda, uma moça encenando a dança do ventre. Hoje é a noite da etnia árabe. Simultaneamente, no palco principal, as apresentações se dão. Danças e músicas em tudo tentam lembrar o mundo árabe.

Há uma tenda menor, em realidade uma oca. Nela não existe comida, muito menos típica. Não há trajes típicos, tampouco alguém que tenha suposta legitimidade para ostentá-los. Os diacríticos são outros. Balaios, redes, arcos e flechas, ossos de baleia, se penduram em pilares, pois na oca não há o confinamento impresso pelas paredes presentes nas demais tendas. O público que a freqüenta é bem menor. Compõe-se de alguns curiosos e outros professores e membros da universidade local. Alguns depoimentos coletados numa obra pouco conhecida, mas de reconhecido valor, acompanhados por gra- 
fites feitos por um artista da cidade tentam lembrar a presença indígena naquele lugar.

Outras tendas se intrometem no Parque das Etnias. A preocupação maior destas é o mercado. São barracas de bancos (por exemplo, o do Estado de Santa Catarina - Besc), Previdência Social, imobiliárias, postos de combustíveis, emissoras de rádio e televisão, Polícia Militar, Prefeitura, e a multiculturalista barraca de organização do evento, e juntas empreendem esforços para transformar diversidade e diferenças em negócios.

Não há autoria na criação da 'Quermesse' de Criciúma, embora muitos reivindiquem a 'paternidade'. Para Archimedes Naspolini Filho, escritor, político e assessor de comunicação, "a quermesse é uma tentativa de abafar um pouco o sucesso que um ano antes havia feito a Porca Pipa, festa organizada por mim para a comunidade italiana ... não foi gratuito que no ano seguinte (1989) foi criada a Quermesse”." Já Maria Heloísa Nazário Felipe, professora do ensino fundamental, aposentada e vinculada à comunidade negra do Bairro Santa Bárbara: "A quermesse começou com uma conversa entre a gente. Víamos a necessidade de uma festa no centro, na praça, onde todos se integrassem. Até falei para meu marido à época: 'Amadeu, vamos pegar umas panelas aí e tal e vamos ajudar o pessoal a fazer a festa na praça" ${ }^{25} \mathrm{E}$ ainda, Irma Tasso de Oliveira, funcionária da Fundação Cultural de Criciúma: "Em 1989 não foi iniciativa nossa, do poder público. Ela começou com uma iniciativa do Lions e do Rotary, que queriam angariar fundos pra entidades filantrópicas. Neste momento a quermesse está ligadíssima às entidades filantrópicas e beneficentes". ${ }^{26}$

Diríamos que há mesmo um caráter doméstico numa quermesse. Uma festa para consumo interno. Sim, pois o cosmopolitismo presente hoje em Criciúma por certo é de um momento posterior, ele é por assim dizer engendrado no calor da hora. Quando do início da quermesse realizada em Criciúma, em 1989, a festa era tímida, de caráter caseiro ou doméstico, realizada 'a toque de caixa', pouco divulgada, enfim de consumo interno ou 'para a cidade'. Pode-se afirmar que foi a partir de sua terceira edição, em 1991, vinculada a outras tantas manifestações - por exemplo, a resistência ao processo de privatização da Companhia Siderúrgica Nacional, que alterava sensivelmente o mundo do trabalho em Criciúma - , que a Quermesse, ou Festa das Etnias, passou a se consolidar como um grande evento, de projeção regional. A hora é aquecida pelo fogo que nela atiça a segunda administração do prefeito Altair Guidi, que desde a primeira edição da festa não medirá esforços para projetá-la, priorizando a capacidade de promover encontros e celebrar a cidade. 


\section{DiSPUTAS ÉTNICAS}

A idéia de uma vitrine viva para apresentar as diversas etnias, 'resgatadas' e 'performatizadas' para dar visibilidade a uma cidade multi-étnica, encontra na Quermesse um bom horário de exibição. Diferente das cidades de colonização germânica dos vales do Itajaí-Açu e o Itapocu, ou de outras, como Florianópolis, Lages e Itajaí, ${ }^{27}$ Criciúma não faz parte do circuito das festas que entraram no calendário turístico de Santa Catarina. Além disso, as cidades de colonização alemã exploraram a sua origem étnica para compor cenários étnicos, na dinâmica da indústria do turismo, fato que trataremos mais adiante. Criciúma sempre foi conhecida pela sua intensa atividade mineradora, a "Capital Nacional do Carvão", desde o Estado Novo de Getúlio Vargas, cuja classe trabalhadora, politicamente mais organizada e combativa que em outras regiões do estado, puxou vários movimentos sociais.

Diferente de outras cidades catarinenses citadas (Blumenau e Joinville), Criciúma não foi (ou não é) reconhecida como 'terra de italianos', ou 'cidade negra' ou 'lugar de alemães', mesmo diante das anuais exibições postas na "Quermesse: Tradição e Cultura", estabelecida como "Festa das Etnias" em 2002.

Apesar da dificuldade em encontrar dados precisos sobre o contingente de descendentes de italianos, pois eles variam muito conforme os referenciais adotados — subjetivos e objetivos — a exemplo da aquisição de dupla cidadania, ${ }^{28}$ ou ainda a tensa relação Jus Soli e Jus Sanguinis — em que a prática de admitir o local de nascimento como fator determinante se relaciona a uma outra que privilegia a descendência —, é visível que em meio à imigração européia deslocada para o Sul de Santa Catarina, desde a segunda metade do século XIX, os italianos são maioria expressiva, o que ocorre também em outras regiões do estado como a Oeste e o Alto Vale do Itajaí (cidades de Ascurra e Rio d'Oeste são exemplos). Em Criciúma, por razões inúmeras, fundadores do núcleo, primeiros comerciantes e políticos, os italianos formam um contingente significativo nas correlações de forças dispersas na cidade. E, apesar da realidade dos números - mesmo não sendo exatos — que indicam uma variada origem étnica na formação da cidade, os de origem italiana constituíram a elite branca no auge da extração do carvão. Com a decadência das minas, a partir de 1980, a cidade precisou se inventar e se propagar, lançando mão, não sem disputas - a elite branca, de origem italiana, fez esforços para se enaltecer pela sua ação colonizadora - da face 'terra das etnias. ${ }^{29}$

É nesse sentido que se projeta a Quermesse: Tradição e Cultura, em 1989, 
que a cada ano faz emergir, grosso modo, uma nova etnia, variando seu número de acordo com as etnias que se apresentam na festa. Assim, Criciúma se investiu, também, de uma forte concepção étnica e produziu um mercado étnico, pelo menos interno. Não um mercado delimitado perfeitamente, um espaço físico onde se possam comprar souvernirs ou coisas do tipo, como nas cidades germânicas, afora o espaço da festa, embora alguns produtos sejam atualmente vendidos pelos camelôs na cidade: bonés e camisetas, por exemplo. Mais significativas são as manifestações subjetivas, imaterializadas. Laços como o relacionamento de uma determinada expressão étnica, especialmente aquelas de formação italiana, mas também outras, a exemplo da alemã, negra e polonesa. Em Criciúma, italianos, alemães, poloneses, negros, árabes, espanhóis e outras formações, sendo a mais recente a indígena, são enaltecidas pelo poder público e pelas associações étnicas e assistenciais.

É necessário cuidado para não tomar como pronta a observação de Ítalo Calvino quando diz que "a cidade diz tudo o que você deve pensar, faz você repetir o discurso e enquanto você acredita estar visitando Tamara, não faz nada além de registrar os nomes com os quais ela define a si própria e a todas as suas partes" ${ }^{30}$ Tentando apanhar as partes de uma vitrine viva e estilhaçada é que se pode pensar uma cidade contemporânea. Para lembrar Baudelaire: "de uma cidade a história muda mais que um coração infiel". Um visitante qualquer ao chegar a Criciúma (e que não a traga no coração ou na mente) o que vê? Uma cidade italiana? Onde? Uma cidade mineira, congelada nos monumentos tal qual o frio que a assola no inverno? Que importância têm para o visitante os nomes que encontra na cidade: Benedet, Castelan, Arns, Omari, Santos, Carneiro? Estas reflexões são especialmente importantes para se entender uma cidade que se constrói, da cultura material à subjetiva, sob referências híbridas. ${ }^{31}$ Isto se pode verificar nas manifestações que irão produzir o fruto chamado Quermesse: Tradição e Cultura. Ainda 1980, quando da comemoração do centenário da cidade, e num momento em que ainda a mineração promovia uma identificação forte de seus habitantes com a 'capital brasileira do carvão'. Contudo, economicamente a cidade já apresentava diferenças que se representavam através de outros setores como o têxtil, o calçadista, o cerâmico e o metalúrgico. Parte de um projeto político mais amplo, em 1981 o então prefeito arquiteto Altair Guidi, em sua primeira gestão, completa o calendário das comemorações do centenário, inaugurando o Paço Municipal, composto não só pelo prédio administrativo da prefeitura, mas também por um memorial da cidade, um teatro, uma biblioteca e um ginásio de esportes dispostos num enorme Parque, à época chamado Centenário. Esse é 
o espaço praticado, ou seja, o lugar onde hoje se realiza a Quermesse de Tradição e Cultura: Festa das Etnias — pela décima oitava vez, em 2006. Podemos afirmar que a cada ano se realiza uma festa diferente.

\section{A CIDADE IMAGEM}

Aqui vamos falar de um feito. As cidades germânicas dos vales do ItajaíAçu e do Itapocu, em Santa Catarina, cidades de pequeno ou médio porte, transformadas em cidades típicas, com suas 'ilhas' turísticas, na década de 1980, são feitas de imagens. Imagens presas em pequenas ilhotas por onde o turista passa. Cidades dentro da cidade. O centro de Blumenau, a cidade da Oktoberfest, ${ }^{32}$ com seu casario enxaimel, suas ruas muito limpas, floridas, junto à orla do rio, tem a aparência de uma mini-cidade, cinematográfica. Na invisibilidade, os bairros operários, as ruas pouco cuidadas e equipadas, as favelas. Em Brusque, o recanto ecológico com seu gramado muito bem cuidado, um verde exuberante, forma o pano de fundo sobre o qual a nova arquitetura, de estilo enxaimel - o prédio da prefeitura, o novo fórum, o Hotel Montes - foi edificada; mais parece um quadro naturalista, que se destaca e se separa, suspenso, longe da cidade cotidiana, com suas fábricas, o comércio, o trânsito, prédios e casarios próprios de uma pequena cidade industrial. Em Joinville, a 'cidade das flores' ou 'dos príncipes', com suas belas palmeiras, contrapõe-se à área de manguezais, para onde acorrem os trabalhadores, na busca de moradia.

A topografia urbana dessas cidades-imagem não é pensada, nem é vista, nem é representada, como um todo geométrico e previsível, integrada em suas conexões totalizantes, próprias das cidades modernas, do século XIX ou inícios do XX. Só podemos pensar nelas a partir do heterogêneo, do acidental, da desintegração da antiga paisagem funcional. Projetadas como imagem, estetizadas para o consumo turístico, são objetos não só do saber do cientista social, mas, e principalmente, em toda sua expressão; são olhadas, pensadas, concebidas, representadas, criadas, detalhadas, esquadrinhadas, com seus contornos delineados, como num panorama exibido na rotunda, uma forma de arte e entretenimento nos finais do século XIX, sem franjas nem fissuras. Essa cidade-imagem é investida pela ação de novos planejadores urbanos.

Aqui, a autoria é visível e reconhecida. Acompanhamos, nas atas das reuniões da Comissão Municipal do Turismo de Blumenau — homens de cultura, empresários, administradores municipais —, entre os finais da década de 
1960 e a década de 1970, semana a semana, o trabalho de construção da 'ilha' turística. Esse trabalho antecedeu à grande festa turística, a Oktoberfest, que desde 1984 atrai, a cada ano no mês de outubro, milhares de turistas nacionais e internacionais. A Comissão de Turismo preparou o cenário da cidade germânica para realizar a festa germânica. Emergiu um novo sujeito de saber e de poder, que inventa e cria a cidade turística, concebida como cidadeimagem, cidade-cultura, cidade-festas, cidade-eventos, cidade-ecológica, cidade-saneada, cidade-jardim, cidade-congresso. Na criação dessa nova cidade, seus olhares detalharam o centro da cidade, a zona turística. Cada canto, cada rua, cada casa, cada transeunte, tudo é olhado, observado, controlado, reformado, inventado para essa nova geometria da cidade: o quadrante turístico. Na Comissão Municipal do Turismo, lugar institucional dessa invenção em Blumenau, os novos sujeitos sociais, sem serem especialistas do saber, como os do século XIX, pesquisam, inventam, olham, interpretam, planejam, para construírem uma cidade germânica. A Comissão organizou e publicou em 1969 um encarte na revista Seleções, de circulação nacional, intitulado “Adivinhe que país é este?", tornando Blumenau conhecida do resto do país, como uma "Alemanha brasileira". Com fotos de várias casas de "telhadinho em pé, todos juravam que era a Alemanha". O folder, com referências a paisagens arquitetônicas da Alemanha, da Áustria, da Escócia, Suíça e Luxemburgo, garantia: "Sim, é Brasil. Blumenau é um pedaço diferente do Brasil que você conhece: ... casas saídas dos contos de fada, cercadas de flores, cortinas nas janelas e (às vezes você poderia jurar) paredes de confeitos e chocolate... Faça sua viagem ao exterior sem sair do Brasil”. A paisagem arquitetônica, formada pela reunião das fotografias impressas no folder, dava a aparência de conjunto, mas na realidade esses traços germânicos eram apenas traços dispersos do que restava de uma arquitetura enxaimel, cuja técnica de construção de encaixe de madeira trançada já caíra em desuso muito tempo antes.

Se anteriormente Blumenau já era uma atração turística pelos seus cristais, instrumentos musicais e confecções, ou como um recanto para casais em lua-de-mel, a partir da década de 1970 investe-se nela para que potencialize seu lado germânico. A cópia, sem pretensão à veracidade, encerra o seu estatuto de autenticidade nela mesma, como obra do seu próprio tempo. Não tem a pretensão de ser mais do que é na sua própria aparência; de história tem apenas citações do passado. Este se realiza como uma artificialidade autoconsciente, que vê ironicamente a fabricação de suas próprias raízes. A questão do genuíno, do autêntico, da integridade não é posta em jogo. Vem daí a força 
da teatralidade nessas construções arquitetônicas, assim como o apelo ao entretenimento, ao kitsch e à cultura de massa.

\section{ARQUITETURA IDENTITÁRIA}

No jornal Artefatos introduziu-se uma matéria, cuja manchete era Reciclagem + Criatividade $=$ Revitalização Enxaimel. Num dos itens, intitulado "Poesia visual Enxaimel", lê-se:

Senhoras e Senhores passageiros, sejam bem-vindos à nossa rápida, porém fascinante viagem ao universo enxaimel ... relaxe seu corpo... e deixe sua mente aberta para a imaginação, cultura e história ... Como o tempo é relativo, nossa fabulosa nave percorrerá em instantes o Túnel do Tempo para pousar no continente Europeu ... Ano de 1598 e/ou 1995. Isso mesmo! No ano que vem, 1996, será reinaugurado o teatro enxaimel em que Shakespeare reinou com suas inúmeras peças... ${ }^{33}$

Num jogo de imaginação, portanto, essa matéria embaralha tempos e espaços, e o autor induz o leitor, cujo corpo físico não sai do lugar, a fazer seu corpo imaginal viajar por terras sem fronteiras: "você se encontra no Sul do Brasil, cidade de imigração germânica. $\mathrm{O}$ auge desta arquitetura está retratado no período de colonização (1850 a 1875) até a fase de consolidação em cidade (1875-1930)".

Nesse tempo parado, suspenso, Shakespeare pode ser ambientado em 1598 ou em 1995, tanto faz. Os espaços sem distâncias, pelos recursos atuais de comunicação, que tornaram possível a transposição de idéias, informações, imaginários, modelos etc., podem juntar Europa e Brasil no mesmo cenário urbano. O castelinho da loja Moellmann, em Blumenau, foi inspirado na Prefeitura de Michelstadt, Alemanha. Transformou-se num dos pontos mais fotografados do Sul do Brasil, um ícone turístico, cartão postal de Blumenau. De fato, na cena expõe-se a cópia do modelo, que dá vida às fantasias e extravagâncias de citações germânicas, em muitos casos, facilitadas pelos avanços tecnológicos e materiais sofisticados da atualidade. O Banco do Brasil em Pomerode é um exemplo da substituição do madeiramento exterior, de estilo enxaimel antigo, pelo aço escovado, permitindo derrubar as fronteiras temporais. É essa tendência ao espetáculo, que a arquitetura pós-moderna evidencia. O compromisso apenas com a beleza, desconsiderando o tempo e afirmando a imitação, pode causar, num primeiro momento, uma sensação 
de desconforto, mas que é logo superado pela familiaridade com essa reprodutibilidade técnica das coisas, no mundo contemporâneo.

Tratar neste momento da arquitetura em Blumenau e nas cidades do Vale é, pois, enfrentar de alguma forma essa arte que se tornou referência obrigatória na interpretação da cultura contemporânea, a qual se manifesta como comunicação, tornando a própria cidade um discurso. É uma arquitetura que rompe com a idéia modernista, de despojamento, racionalidade e funcionalismo, e assume o desejo de ser sensível à tradição, à história, aos princípios estéticos, embora não se possa dizer que a consecução desse projeto seja desinteressada como fim em si mesma. ${ }^{34}$

Na construção dos edifícios típicos, deliberadamente, os 'militantes' pela construção da "Alemanha Brasileira" investiram na criatividade atual, sem pretensão à originalidade. Acompanhando a leitura das atas das reuniões da Comissão Municipal de Turismo, na década de 1970, percebem-se os dilemas e os desafios para a criação da arquitetura típica. Os membros da Comissão foram buscar modelos em Campos de Jordão e Gramado, no Brasil, e também na Alemanha. Solicitaram a criação de lei que isentasse de impostos as construções de casas típicas, bem como incentivaram a oferta pela prefeitura de planta arquitetônica aos interessados. Sugeriram critério de julgamento do que seria típico. Trabalharam pela preservação do patrimônio...

Se "a única coisa que Blumenau podia vender, em termos de Blumenau, era o seu lado germânico", ${ }^{35}$ a fachada arquitetônica como elemento de evocação à tradição forma uma nova aura para as mercadorias produzidas localmente. O conjunto formado pela mercadoria, com suas etiquetas Made in Brazil, e a sua habitação, a casa comercial de fachada germânica, é um atrativo turístico. E o conjunto do casario, comércio, hotéis, repartições administrativas, bancos, restaurantes etc., forma o cenário da cidade-imagem, o qual conquista os turistas, não só durante o período das festas turísticas, mas também no resto do ano, podendo ser tomado como uma forma discursiva associada ao mercado turístico. Abordar a arquitetura neo-enxaimel nas cidades das festas germânicas é compreender como se estava construindo a grande metáfora da história, criando cenários da cidade, espetáculo da cultura que se revela como autêntica. Confundida com tradição, realiza o espectro do simulacro, onde a cópia é superior ao próprio original. ${ }^{36} \mathrm{~A}$ arquitetura que se veste para o turista é eloqüente, saturada de pastiche e faz reclame de si mesma. Isto é, o visitante não se equivoca; as referências históricas são explicitas, é a 'indústria da tradição histórica." ${ }^{37}$

A cidade turística tornou-se, portanto, um modelo. Feita para o turista 
como cultura espetáculo para fruição e admiração, ela deve ser limpa, estetizada, harmônica, ecológica. Feita para ser contemplada, sua imagem é enquadrada num espelho. Presa na moldura, a cidade deve eliminar suas rugas, suas manchas, seus desalinhos. O feio não se mira no espelho. Somente o belo contempla a sua imagem e se deixa fotografar para a reprodução da sua imagem. E a cultura turística é a cultura fotogênica.

\section{A ETNIA NARCÍSICA}

Nas cidades turísticas étnicas, dos vales do Itajaí-Açu e do Itapocu, seus habitantes também compõem o cenário turístico. O quadrante turístico da cidade é construído como um objeto global de saber e intervenção, mesmo sobre os habitantes. Seus corpos também são submetidos a uma norma para que se tornem códigos da germanidade. Produzidos para serem mostrados na festa, o grande acontecimento turístico, nos desfiles, nos shows folclóricos, nas bandas musicais, nas lojas, nos serviços, nas ruas, seus corpos devem se conformar aos códigos étnicos da germanidade. Povo ordeiro, trabalhador, limpo, progressista, mulheres e crianças louras, saudáveis, bem coradas. É a germanidade do povo que é prometida ao turista, com seu casario enxaimel, os gerânios nas sacadas, os jardins bem cuidados, as ruas e os sanitários muito limpos e, especialmente, moradores que 'preservam o ethos germânico': o trabalho, a limpeza, o capricho dos bordados, um gosto especial pela culinária e pelos quitutes, uma tradição musical.

A cidade, o quadrilátero da cidade fotogênica, é produzida como um objeto global, portanto. O plano de ação sobre a construção da cidade-imagem constrói também seus moradores. Estetiza-os porque, da imagem de cidade germânica, o habitante é o principal componente. Diferente de outras cidades turísticas - Paris, por exemplo, onde o turista não depara com o francês típico. É só uma multidão de turistas e uma pluralidade de idiomas. $\mathrm{Ou}$, nas cidades étnicas peruanas, como Cuzco, onde índias vestidas em seus trajes típicos passeiam com lhamas para que os turistas possam tirar suas fotos. $\mathrm{Pa}$ recem, entretanto, deslocadas no cenário da cidade, artificiais, ainda mais quando cobram pela foto um preço predeterminado. Nas cidades germânicas de Santa Catarina, tudo parece 'natural'; tem sabor de verdade.

Assim, o investimento sobre os trabalhadores já não é aquele do século XIX. A cidade moderna problematizou a população sob dois aspectos: por um lado, controlar, esquadrinhar, disciplinar, reformar o povo, atingindo seu 
cotidiano no que diz respeito à moradia, ao lazer, à sexualidade, aos hábitos alimentares etc.; por outro, foi necessário criar uma nova cultura, a cultura do trabalho fabril. O ritmo das máquinas, as jornadas de trabalho sob o império do relógio, o uso dos equipamentos do patrão, o trabalho por salário, tudo isso exigiu uma formação sociocultural. Ainda podemos acrescentar a isso as questões dos movimentos sociais que exigiram novos paradigmas das ciências para explicar os processos de acumulação do capital, a positividade do trabalho, a legitimidade da propriedade, a natureza dos governos liberais.

Nas cidades turísticas do Vale, além de que novos trabalhadores estão sendo criados, educados, formados, para novas funções - recepcionistas, taxistas, cicerones, guardas-mirins, engraxates, balconistas — , ainda devem ser vistos pela ótica da estetização e do ethos da germanidade: ordeiros, limpos, bem educados. Eram recorrentes, nas atas das reuniões da Comissão Municipal do Turismo de Blumenau, campanhas para instruir as crianças na limpeza da cidade; reclamou-se de que os empregados das lojas jogavam lixo na cidade; sugeriu-se a criação de pequenos cicerones, mantidos pela Prefeitura, a exemplo de Ouro Preto; solicitou-se um curso para garçons da cidade, no Senac; sugeriu-se um curso de psicologia de vendas para balconistas; instituiuse um projeto de criação da guarda-mirim, com instrução profissional e uso de uniforme, visando acabar com a mendicância; fez-se uma proposta de seleção de moças para acompanhar senhoras turistas. Sugeriu-se que os engraxates fossem instruídos para atender os turistas e que se acolhessem os mais educados e inteligentes; a Comissão de Trânsito investiu na formação, aparência e bons modos dos taxistas.

Na invenção dessa cidade étnica, há uma profunda imbricação entre o saber sobre o que é a sociedade real e o projeto de reforma e educação dos habitantes para se tornarem membros de uma sociedade ficcional. Afinal, a cultura tornou-se uma mercadoria, uma mercadoria simbólica, feita de ilusão e imagem, que não se aliena de seus sujeitos. O trabalhador encarna essa mercadoria ou a mercadoria é encarnada no corpo do trabalhador. Ao vender uma estada em um hotel alemão, o atendimento feito pelo/a recepcionista, a cama arrumada pela camareira, o chão limpo pela mulher alemã, o café servido e a culinária alemã, tudo isso vem revestido da aura da germanidade. Portanto é preciso que esses trabalhadores vistam a alma alemã, e o fetiche da mercadoria vem apenas do valor-trabalho agregado. Há também valor-simbólicocultural-imagético agregado no processo de mercadorização cultural. 
Na construção e invenção dessa cidade típica, já não se vêem os antigos muros das cidades medievais, separando o que está dentro do que está fora da cidade, os burgos. No entanto, os contornos dessa nova cidade são desenhados com sua orla ficcional - ficção que não significa falsidade, e sim, construção da cidade alemã, que se dá, não apenas simbolicamente, mas fisicamente também, com o tratamento dos morros à vista, do rio que acompanha a paisagem - formando a orla física dessa cidade. Na cidade estetizada, típica, turística, refletida no espelho da germanidade, os mendigos, os estranhos, são colocados na invisibilidade, fora do alcance dos olhos do turista. A Comissão de Turismo de Blumenau solicitou às autoridades que evitassem construções de barracos às margens do rio para não dar má impressão aos turistas. Pediu ao prefeito que mandasse pintar as casas das favelas à vista do turista. Os morros, que costumeiramente têm se transformado no 'espetáculo da pobreza', pela formação de favelas, foram preenchidos pelo verde e pela ocupação turística. O turismo subiu o morro, poderíamos dizer. Essa ação pode ter dois efeitos. Se por um lado a vista a partir da cidade alcança o morro com sua paisagem compondo o cenário luzidio, verde, de outro o turista subindo o morro, sua vista alcança a cidade com seu casario típico, seu traçado bem cuidado, a silhueta do rio cortando a paisagem urbana, de cuja história faz parte. ${ }^{38}$

As 'funções' do morro (termo antigo da sociologia) refletem o olhar sobre a cidade: o olhar do lazer, do prazer da contemplação da vista, no duplo sentido da palavra: da nossa vista e a vista da cidade..$^{39}$ Misturado a esse olhar, especialmente nos tempos mais recentes, nossos imaginários sobre os morros das cidades são repletos de imagens de perigo e violência. Lugar de moradia dos pobres, abrigo dos bandidos, o morro é sinônimo de favela, onde habitam os operários, trabalhadores desempregados, junto a bandidos, traficantes, organizações criminosas. O morro tornou-se, desde então, ao mesmo tempo, imagem de moradia e de abrigo dos mais pobres, lugar dos 'desclassificados'. Da mesma forma, a rua é associada à idéia de prazer e de perigo. Lugar de passagem, mas também lugar de reunião — manifestação política, festividades, mesas de bares e restaurantes, comemorações - a rua deve ser controlada, vigiada, iluminada:

Lugar de prazer oral, mas também sexual, pois o trottoir é feito nas ruas. As ruas foram consideradas desde cedo pela polícia e pelos médicos como lugares 
de perigo. Perigo de contágio, perigo de violência, individual e coletiva. O esquadrinhamento dos quarteirões, numa combinação de poder médico, é muito praticado segundo a ótica higienista, desde o final do século XIX. Atualmente, nossas ruas continuam a justificar e a intensificar o imaginário dúbio do prazer/perigo. ${ }^{40}$

Mas não no quadrilátero turístico. Na Blumenau turística, as ruas também foram cuidadas e receberam iluminação. Nas reuniões da Comissão, solicitou-se iluminação do footing aos domingos; reclamou-se das mesas de bar nas calçadas. Herbert Hering solicitou um guarda para o horto nos fundos da Biblioteca Pública, impedindo que se cace no local. Sobre isso Günther Steibach sugeriu que os escoteiros e bandeirantes vigiassem o local em troca da exploração de um bar. Sobre esses controles de locais, ainda se pode falar de iluminação de ruas escuras 'para evitar perigo contra as moças', e da troca do nome do hotel Veraneio, porque os turistas duvidam da sua seriedade.

Quando se vai a um parque de diversões, Beto Carrero World - uma espécie de Disneylândia, em Navegantes - , ou ao Play Center, em São Paulo, por exemplo, depara com várias coisas montadas em imagens virtuais, uma mini-cidade, a caverna dos piratas etc., que por mais que se pareçam com o real, pela pintura envelhecida, os musgos cobrindo o cimento para imitar rochas, as personagens mecânicas, de cera ou empalhadas, misturadas com atores que interagem com o público, sons imitando vozes de animais etc., sabese que não passam de metáforas. Outras cidades-diversão, como World Sacramento, dentro da cidade de Sacramento, capital da Califórnia, por exemplo, imitando cidades do Velho Oeste americano, são como ghost towns ${ }^{41}$ montadas exatamente como o eram há cem anos atrás. A vendedora está vestida à dama antiga, o mocinho de cowboy. É pura imitação. Mas imitação, no traçado da cidadela, na arquitetura, a velha escola, a estação do trem, o comércio, o saloon, e o turista participa da ficção, como participante dessa 'feira comercial', como brincadeira do 'faz de conta', no cenário montado como teatro.

Outras cidades-diversão concentram-se sobre o jogo e o espetáculo. Las Vegas é um exemplo: com sua arquitetura totalmente artificial, é uma cidademensagem, toda construída de signos, "não uma cidade como outra qualquer, que comunica para poder funcionar, mas uma cidade que funciona para comunicar". É uma cidade 'verdadeira'. ${ }^{42}$ Assim são as cidades germânicas nos vales do Itajaí-Açu e do Itapocu, em Santa Catarina. Cidade comunicação. Tudo é feito para comunicar a germanidade, para se transformar na "Alemanha Brasileira”. Não como um passado representado, mas como um presente 
vivo. Não só na semiologia topográfica ou iconográfica, mas na leitura dos próprios corpos, da língua, da música, da dança. Os moradores são performatizados, nos serviços, nos desfiles, na apresentação dos grupos folclóricos e das bandinhas típicas, que infestam os bares e casas noturnas e outros espaços de espetáculos, com seus shows e música alemã.

\section{CONCLUSÃO}

Esses investimentos na re-invenção da tradição por parte do governo e de grupos econômicos e intelectuais, fundamentados nos elos de ligação com a história e a geografia, devem, no entanto, suscitar interpretações. O discurso afirma que a preservação do patrimônio histórico contribui para a formulação ou para o reforço de uma identidade cultural, ou para a preservação da memória histórica. Nem identidade, nem memória coletiva, nem preservação da tradição, nas sociedades modernas e contemporâneas, têm autonomia ou natureza próprias. A especificidade desses processos conflui para questões bem localizadas historicamente. Falar de preservação de bens culturais, qualquer que seja o sentido da expressão, pressupõe sempre um desejo de continuidade, em função, precisamente, da alimentação da identidade cultural. No entanto, as identidades, sempre transitórias, são politicamente atribuídas e politicamente mantidas, e se transformam politicamente; a identidade pode ser esquecida, abandonada, perdida ou inventada, construída. Sendo assim, o processo de criação de identidade é um processo de criação de imagem, dentro dos propósitos que se abrem em sua própria contemporaneidade.

Jameson refere-se à transformação da cultura em economia e da economia em cultura. "A cultura é negócio, e produtos culturais são feitos para o mercado". ${ }^{43}$ A explosão da cultura na esfera econômica, na definição de Jameson, faz a imagem assumir a forma mais acabada da mercadoria. Tudo é performático, tudo é mercadorizado no espetáculo dos meios de comunicação, que tudo vende, seja informação, seja comunicação, e acaba por informar/produzir a opinião pública e como tal estimula a conscientização, dotando as elites administrativas de um meta-discurso acerca do turismo como potencial econômico, que o turismo e cultura andam juntos e que a tradição deve ser estimulada.

Convém lembrar que se não se começar a tentar entender qual a direção assumida pelos valores e modelos de comportamentos que as novas cidades inventam, "as formas ainda mais inovadoras e de vanguarda, a expansão ili- 
mitada da cultura de massas, não se compreenderá nunca como são os pontos de referência, as distorções das partes mais marginalizadas de qualquer país e principalmente do Brasil"."

Em Santa Catarina, a maioria das cidades, principalmente as que oferecem alguma possibilidade de emprego, têm visto suas periferias crescerem, em decorrência do êxodo rural. Em Blumenau, a Análise Sócio-Econômica da População Urbana, realizada pelo Instituto de Pesquisas Sociais da Furb, em 1994, detectou que o número de migrantes já é maior na composição da população. No Centro da cidade 57,10 por cento dos habitantes são de fora. "Os descendentes de alemães já não são a maioria” conclui a pesquisa. ${ }^{45}$ De 1904 a 1989, os migrantes somavam 44,69 por cento da população. Em 1991-1992, aumentaram para 50,37 por cento dos habitantes. ${ }^{46}$

Em 1993 noticiava-se que havia 12 bolsões de miséria em Blumenau e que, para estancar o povoamento desses focos de pobreza, a cidade aderiu ao movimento de orientação à migração, integrada por outros municípios da região, cujo princípio inicial é "nunca transferir o problema em que o migrante se transformou para outra cidade ... Quando a situação exige, o carente recebe passagem de ônibus para retornar a sua cidade de origem". ${ }^{47}$ Novamente, em 1994, lê-se: "Crescem restrições para migrantes em Blumenau — Favelização da cidade leva prefeitura a jogar duro na recepção aos trabalhadores de fora". ${ }^{48}$ As análises apontam que a maioria dos migrantes vêm sem condições de emprego e habitação. Uma das causas apontadas para a procura por Blumenau é o próprio turismo. "Para desenvolver o turismo, divulgamos o desenvolvimento da cidade e esquecemos das implicações que isso vai acarretar". ${ }^{49}$

Alcançado ao menos uma década de discussão substancial sobre fenômenos que em tudo se relacionam a processos de internacionalização do mundo, e que apenas muito recentemente — historiadores, sociólogos, antropólogos e geógrafos e outros tantos estudiosos - chamamos de globalização, as configurações que se tramam a partir de manifestações econômicas, sociais e culturais como a constituição de blocos econômicos, de agilidade na informação e de elasticidade ou alargamento de fronteiras, transportam a singularidade, pouco discutida é verdade, de mostrar a todos e a cada um, para usar uma expressão de Otávio Ianni, que “afinal somos parte da humanidade”. Perplexidade que assusta pela frieza do real - enfim nos mostramos ao mundo, o chamado Terceiro ou Quarto Mundo - e também pelo que esta narcisa configuração gera de exclusão e acirramentos.

$\mathrm{Na}$ ambiência da "comunidade politicamente imaginada" ${ }^{50}$ são produzi- 
das transformações sensíveis em relação à cidadania, à comunicação, à flexibilidade do mundo do trabalho e tantas outras. É nessa fluidez, na vazante líquida da modernidade ${ }^{51}$ que se abrem novas possibilidades de abordagem do contemporâneo. Assim, "admirável ou não, trata-se na verdade de um mundo novo". ${ }^{52}$ A cidade é uma instância significativa nessa desordem que se coloca. É nela que, por assim dizer, a vida acontece. Para aqueles que têm nela seu foco de estudo, torna-se um desafio diário a compreensão dessa pulsante existência. Ouvir as músicas que as cidades cantam — e todas as têm em suas harmonias e desafinações - é de alguma forma vislumbrar a sinfonia de cada uma. Numa quermesse de um pequeno e distante vilarejo, em outra eletrônica, ou noutra realizada durante o dia do orgulho gay, ${ }^{53}$ o caráter celebrativo e exibicionista se faz sempre presente. Há algo que precisa ser mostrado. É desta forma que podemos visualizar a cidade como uma grande vitrine. Iluminação, opacidade ou translucidez são nuanças dessa cidade-vitrine. Uma vitrine viva.

Ou, para retomar uma imagem que introduzimos no título deste artigo: a imagem do carrossel, simultaneamente antigo e atual, que provoca vertigem, algo como a proliferação de sinais, luzes e cores que a cidade contemporânea emite. Em recente disco, o grupo de rock Skank faz alusão ao Carousel of Souls, do artista plástico norte-americano Glenn Barr, alguma coisa próxima do surrealismo de hoje.

\section{NOTAS}

${ }^{1}$ JEUDY, Henri-Pierre. Espelho das cidades. Rio de Janeiro: Casa da Palavra, 2005. p.100.

${ }^{2}$ HOLLANDA, Heloisa Buarque de. Introdução. Revista do Patrimônio Histórico e Artístico Nacional, Brasília: Iphan, n.23, 1994, p.15.

${ }^{3}$ PESAVENTO, Sandra Jatahy. O imaginário da cidade: visões literárias do urbano - Paris, Rio de Janeiro, Porto Alegre. Porto Alegre: Ed. UFRGS, 1999. p.391-3.

${ }^{4} \mathrm{~A}$ bibliografia sobre cidades no Brasil é extensa. Paradigmático no início do estudos sobre a cidade moderna foi: BRESCIANI, Maria Stella M. Permanência e ruptura no estudo das cidades. Conferência. Florianópolis, UFSC, 1991. Dentre os trabalhos mais recentes, organizados por essa autora, citamos:BRESCIANI, Maria Stella M. (Org.) Imagens da cidade: séculos XIX e XX. São Paulo: Anpuh; Marco Zero; Fapesp, 1993; e Palavras da cidade. Porto Alegre: Ed. UFRGS, 2001.

${ }^{5}$ CANEVACCI, Massimo. A cidade polifônica. São Paulo: Studio Nobel, 1993. p.38. 
${ }^{6}$ BIDOU-ZHACHARIASEN, Catherine (Coord.) De volta à cidade: dos processos de gentrificação às políticas de 'revitalização' dos centros urbanos. São Paulo: Annnablume, 2006.

${ }^{7}$ SARLO, Beatriz. Paisagens imaginárias: intelectuais, arte e meios de comunicação. (Trad. Rúbia Prates e Sérgio Molina). São Paulo: Edusp, 1997.

${ }^{8}$ GUPTA, Akhil; FERGUSON, James. Mais além da 'cultura': espaço, identidade e política da diferença. In: ARANTES, Antonio A. (Org.) O espaço da diferença. Campinas: Papirus, 2000. p.30-49. p.32.

${ }^{9}$ A identificação nunca é a afirmação de uma identidade pré-dada, tampouco, de uma atividade pré-cumpridora. E é nesse espaço suplementar que "o povo como forma de interpelação emerge do abismo da enunciação onde o sujeito se divide, o significante 'desaparece gradualmente' e o pedagógico e o performativo são articulados de forma agonística". BHABHA, Homi K. O local da cultura. (Trad. Myriam Ávila, Eliana Lourenço de Lima Reis e Gláucia Renate Gonçalves). Belo Horizonte: Ed. UFMG, 1998. p.217-8. Ver também na mesma referência: Interrogando a identidade: Frantz Fanon e a prerrogativa pós-colonial, p.70-104. E ainda, como colaboração, ver: HALL, Stuart. Quem precisa da identidade? In: SILVA, Tomaz Tadeu (Org.) Identidade e diferença: as perspectivas dos estudos culturais. Petrópolis: Vozes, 2001.

${ }^{10} \mathrm{O}$ hiperespaço é teorizado, em diferentes abordagens, por vários pensadores, entre os quais: Arjun Appadurai, Massimo Canevacci, Marc Augé, Fredric Jameson e Zygmunt Bauman. Esses autores divergem em muitos pontos, mas em todos é possível identificar a preocupação com os elementos que compõem e complexificam o contemporâneo, tais como o trânsito, o lugar e o global.

${ }^{11}$ CERTEAU, Michel de. A invenção do cotidiano. (Trad. Ephraim Ferreira Alves). Petrópolis: Vozes, 1994. p.200-2.

${ }^{12}$ Para maior compreensão desse fenômeno contemporâneo, na cidade de Criciúma, no Sul de Santa Catarina, remetemos a: CAMPOS, Emerson César de. Territórios deslizantes: recortes, miscelâneas e exibições na cidade contemporânea — Criciúma (SC) (1980-2002). Tese (Doutorado em História) — UFSC, Florianópolis, 2003.

${ }^{13}$ Essa citação recupera trechos de algumas músicas do Grupo "Ato Consciente", sob título Dia a Dia em Criciúma. O CD lançado pelo grupo foi uma produção caseira, pois, segundo informação do próprio Willian, é muito onerosa a tarefa de gravar um CD legalizado. É mais um dos inúmeros exemplos de constituição de territórios que se constroem sob a informalidade. Para uma discussão mais elaborada desses territórios da informalidade ver: CANCLINI, Nestor Garcia. Consumidores e cidadãos: conflitos multiculturais da globalização. (Trad. Mauricio Santana Dias). Rio de Janeiro: UFRJ, 1995.

${ }^{14}$ Para isto, ver entre outros: ORLANDI, Eni Puccinelli. Cidade atravessada: os sentidos públicos no espaço urbano. Campinas: Pontes, 2001.

${ }^{15}$ O Clube União Operária, instalado na cidade desde 1937, foi desde sua fundação um território negro. Mais que isso, fez frente a outros territórios, a exemplo daquele forjado pelo 
Clube União Mineira (criado em 1935) localizado no mesmo bairro, onde até fins da década de 1960, "negro não entrava".

${ }^{16}$ Por certo podemos identificar muitas tentativas de consagrar aos lugares uma estabilidade. Quanto à idéia de transformar a cidade num grande museu, ver: AUGÉ, Marc. Não lugares: introdução a uma antropologia da supermodernidade. (Trad. Maria Lúcia Pereira). Campinas: Papirus, 1994. Aliás, entre as concepções de lugares que tentamos discutir aqui, a mais radical nos parece ter sido iniciada por Marc Augé, que assume a idéia de uma supermodernidade e de não-lugares. Contudo, apesar de sedutora, tal perspectiva se constrói sob frágil preocupação com diferenças ou mesmo a com dimensão de poder que, de formas distintas, se tenta impelir a um lugar.

${ }^{17}$ CANCLINI, Nestor Garcia. Consumidores e cidadãos, cit. No caso específico do Rio Maina, em 2003 foi criado um site onde se discute a Emancipação do Distrito em relação a Criciúma, apoiada pelos comerciantes e parte do corpo político, mas rechaçada pela maior parte da população. O endereço, por si, já indica o desejo de fazer parte da cidade: www.criciumaunida.com.br (acesso em out. 2006).

${ }^{18}$ HENRI-PIERRE, Jeudy. Espelho das cidades. Rio de Janeiro: Casa da Palavra, 2005. p.98.

${ }^{19}$ HALL, Stuart. A questão da identidade cultural. (Trad. Andréa Borghi Moreira Jacinto e Simone Miziara Frangella). Textos didáticos, Campinas: IFCH/Unicamp, n.18, dez. 1995, p.61.

${ }^{20}$ Criciúma é, proporcionalmente à população, a cidade com a maior média de pessoas que emigram para outros países, especialmente para os Estados Unidos. Temos trabalhado com este tema ao longo dos últimos dois anos. Para uma discussão consistente desse fenômeno relacionado a Criciúma, ver: ASSIS, Gláucia de Oliveira. De Criciúma para o mundo: rearranjos familiares e de gênero nas vivências dos novos migrantes brasileiros. Tese (Doutorado em Ciências Sociais) — IFCH, Unicamp, Campinas, 2004.

${ }^{21} \mathrm{~A}$ idéia de hibridismo não elimina a problemática dos lugares. Ao contrário, a polemiza ainda mais. O texto hoje clássico de Pierre Nora fala disto: "Lugares portanto, mas lugares mistos, híbridos e mutantes, intimamente enlaçados de vida e morte de tempo e eternidade; numa espiral do coletivo e do individual, do prosaico e do sagrado, do imóvel e do móvel". NORA, Pierre. Entre memória e história: a problemática dos lugares. (Trad. Yara Aun Khoury). Projeto História, São Paulo, v.10, dez. 1993, p.22.

${ }^{22} \mathrm{~A}$ ação titubeante na denominação é sinal muito visível da experiência incerta que mulheres e homens vivem nas últimas duas ou três décadas, mesmo se tivermos na alça da mira a contribuição crítica clássica — na seara aberta por Jurgen Habermas — de que a modernidade ainda acontece. É sobretudo frente a projetos racionais que a incerteza mostra sua face, e para desespero de uma retórica no mínimo renhida, é onde ela se mostra mais produtora de tensões. Por mais dolorosa que seja a ação, é necessário aguçar a sensibilidade. Ver reflexão a respeito em: MAFFESOLI, Michel de. Elogio da razão sensivel. (Trad. Albert Ch. M. Stuckenbruck). Petrópolis: Vozes, 1998.

${ }^{23}$ É neste sentido que o mais conhecido dicionário da Língua Portuguesa no Brasil apre- 
senta o termo: "Do flamengo kerkmisse, pelo fr. kermesse. Feira paroquial que era celebrada anualmente nos Países Baixos, com grandes folguedos populares. Bazar ou feira beneficente, em geral com leilão de prendas". FERREIRA, Aurélio B. de H. Aurélio século XXI: o dicionário da língua portuguesa. Rio de Janeiro: Nova Fronteira, 1999.

${ }^{24}$ Entrevista concedida a Emerson César de Campos, na cidade de Criciúma, em 25 abr. 2001.

${ }^{25}$ Idem, em 28 jul. 2001.

${ }^{26}$ Idem, em 2 set. 2002.

${ }^{27}$ Conforme estimativa da população de Santa Catarina encontrada no IBGE referente a 1999, Criciúma se apresenta como uma cidade de porte médio, contando com aproximadamente 170 mil habitantes. No sul catarinense, é a cidade com o maior contingente populacional, seguida por Tubarão com 87 mil e Araranguá com 56 mil habitantes. Em um total de pouco mais de 5 milhões de pessoas distribuídas no estado de Santa Catarina à época, Criciúma era a $4^{a}$ cidade em número de habitantes, sendo precedida por Joinville com cerca de 430 mil habitantes, Florianópolis com 282 mil e Blumenau com 245 mil habitantes.

${ }^{28}$ A aquisição de dupla cidadania por parte de descendentes de italianos em Santa Catarina é abordada por vários estudiosos, entre os quais SAVOLDI, Adiles. O caminho inverso: a trajetória de descendentes de imigrantes italianos em busca da dupla cidadania. Dissertação (Mestrado) — UFSC, Florianópolis, 1998.

${ }^{29}$ Os dados são bastante contundentes quanto à participação e presença da população negra em Criciúma. Segundo o Anuário dos Trabalhadores do Dieese de 1998, Criciúma se apresenta como a primeira cidade em termos de população negra no estado de Santa Catarina, com um índice de 5,45 por cento da população total do município, seguida por Florianópolis, com 4,12, Itajaí com 2,32 e Joinville com 2,13 por cento. Os dados, contudo, não me parecem indicar o que realmente se encontra na cidade. Do nosso ponto de vista esse número pode ser bem maior. Contudo, mesmo que limitado por critérios formais nem sempre adequados, Criciúma se apresenta, proporcionalmente à sua população, como a cidade com o contingente negro do estado. Dados obtidos em: DIEESE-SC. Anuário dos trabalhadores. Florianópolis: Departamento Intersindical de Estatística e Estudos SócioEconômicos, 1998, p.30. Fechando estes exemplos, agora em relação aos alemães citados anteriormente, o contingente dessa população na organização política do município foi sensivelmente reduzido quando da emancipação política de Forquilhinha, até 1989 um Distrito de Criciúma e para onde se deslocou, desde 1917, a maior parte dos alemães e seus descendentes.

${ }^{30}$ CALVINO, Ítalo. As cidades invisíveis. (Trad. Diogo Mainardi). São Paulo: Companhia das Letras, 1990. p.119. A advertência é posta também por Massimo Canevacci, que em $A$ cidade polifônica dedica um capítulo em sua primeira parte à análise inovadora de Calvino, da qual destaca o olhar cameleiro. Ver: CANEVACCI, Massimo. A cidade polifônica: ensaio sobre a antropologia da comunicação urbana. (Trad. Cecília Prada). São Paulo: Studio Nobel, 1993. 
${ }^{31}$ Para melhor compreensão do hibridismo são muitas as referências, das quais destaco os trabalhos de Nestor Garcia Canclini, Stuart Hall e Homi K. Bhabha. Neste último pode-se destacar: "Para se apreender a ambivalência do hibridismo, ele deve ser distinguido de uma inversão que sugeriria que o originário é de fato, apenas um 'efeito'. O hibridismo não tem uma tal perspectiva de profundidade ou verdade para oferecer: não é um terceiro termo que resolve a tensão entre duas culturas, ou as duas cenas de um livro, em um jogo dialético de reconhecimento". In: BHABHA, Homi K. O local da cultura, cit., p.165.

${ }^{32}$ Para melhor compreensão da criação da Oktoberfest e do circuito das festas germânicas nos vales do Iataí-Acu e do Itapocu, remetemos a: FLORES, Maria Bernardete Ramos. Oktoberfest: turismo, festa e cultura na Estação do Chopp. Florianópolis: Ed. UFSC, 1997.

${ }^{33}$ Artefatos, Blumenau, ano 1, n.3, abr. 1995.

${ }^{34}$ Harvey (cit., p.70) insere a idéia de que a arquitetura pós-moderna, não funcionalista, seria "desinteressada como fim em si mesma".

${ }^{35}$ Entrevista realizada em Blumenau em 28 dez. 1993 com o sr. Emílio Schramm.

${ }^{36}$ ECO, Humberto. Viagem na irrealidade cotidiana. (Trad. Aurora F. Bernadini e Homero F. de Andrade). Rio de Janeiro: Nova Fronteira, 1984. p.27.

${ }^{37}$ HARVEY, David, cit., p.85.

${ }^{38}$ Sobre as obras de um restaurante do Morro do Aipim, o Frohzinn, discutida em várias reuniões da Comissão de Turismo, em Blumenau, tratou-se do plano da chapada e do ajardinamento, do acesso, da iluminação. Na reunião de 27 ago. 1968 "decidiu-se enviar ao prefeito um ofício solicitando que seja impedida a construção de uma casa de madeira ... para não aumentar a favela ali existente”. E na reunião de 10 abr. 1970 o próprio prefeito pediu parecer da Comissão quanto à construção de casas de madeira no Morro do Aipim. Outro morro transformado em ponto turístico foi o Spitztroph, projeto também discutido amplamente e acompanhado pela Comissão Municipal de Turismo, denunciando-se, em reunião de 2 out. 1970, o desmatamento de uma de suas áreas, "prejudicando a beleza natural". Ainda um terceiro morro, o Becausser, é alvo de transformação em ponto turístico. Na reunião de 13 mar. 1970, sugeriu-se que ali se construísse um motel. No enquadramento sócio-geográfico da cidade, o processo de estetização subiu os morros, portanto.

${ }^{39}$ PECHMAN, Robert. Olhares sobre a cidade. Rio de Janeiro: UFRJ, 1994. p.187.

${ }^{40}$ Ibidem, p.191.

${ }^{41}$ ECO, Umberto. Viagem na irrealidade cotidiana, cit., p.54.

${ }^{42}$ Ibidem, p.52.

${ }^{43}$ JAMESON, Fredric. Entrevista concedida a Marcelo Resende. Folha de S. Paulo, 19 nov. 1995, p.5.

${ }^{44}$ CANEVACCI, cit., p.41.

${ }^{45}$ Jornal de Santa Catarina, 22 jul. 1994, p.9.

${ }^{46}$ Ibidem. 
${ }^{47}$ Jornal de Santa Catarina, 7 nov. 1993, p.36.

${ }^{48}$ Jornal de Santa Catarina, 11 ago. 1994, p.9.

${ }^{49}$ Jornal de Santa Catarina, 3 mar. 1995, p.3A.

${ }^{50}$ Expressão cunhada por Benedict Anderson. Nação é um termo caro às ciências humanas desde Hegel, Herder, Max Weber, atravessando toda a historiografia francesa e inglesa, até alcançar discussões inovadoras como as de Benedict Anderson, Eric Hobsbawm e mais recentemente, Stuart Hall e Homi K. Bhabha.

${ }^{51}$ Expressão utilizada por Zygmunt Bauman quando de suas reflexões sobre o mundo contemporâneo. O interessante na obra de Bauman é sua impressionante lucidez frente a fenômenos da contemporaneidade, como a globalização: suas opções políticas e as implicações econômicas ligadas a ela. Para isto, entre outros títulos, ver: BAUMAN, Zygmunt. Globalização: as conseqüências humanas. (Trad. Marcos Penchel). Rio de Janeiro: Jorge Zahar, 1998.

${ }^{52}$ CASTELLS, Manoel. A era da informação: o poder da identidade. v.2. São Paulo: Paz e Terra, 1999. p.17.

${ }^{53}$ A exemplo da quermesse realizada no Arouche (São Paulo) em 27 jun. 2001, durante as comemorações da semana do orgulho gay (gay pride). Foi assim noticiada: "Depois de correr o risco de ser interditada, a Quermesse Gay no Largo do Arouche aconteceu e foi até agora o maior evento da semana do orgulho gay em São Paulo". Internet: www2.uol.com.br /mixbrasil/pride/pride2001/vieira.htm. Acesso em out. 2006. 